УДК 37.018.43:004.78] : 005.953

Коневщинська Ольга Еммануїлівна

кандидат педагогічних наук, вчений секретар

Інститут інформаційних технологій і засобів навчання НАПН України, м. Київ, Україна

olgak1972@mail.ru

\title{
ФОРМУВАННЯ ІКТ-КОМПЕТЕНТНОСТІ ВИКЛАДАЧІВ-ТЬЮТОРІВ РЕСУРСНИХ ЦЕНТРІВ ДИСТАНЦІЙНОЇ ОСВІТИ
}

\begin{abstract}
Анотація. У статті проаналізовано основні підходи щодо формування ІКТ-компетентності у категорії фахівців, які здійснюють навчально-методичну підтримку процесу дистанційного навчання. Висвітлено ступінь наукової розробки проблеми, визначено й обгрунтовано сутність ІКТ-компетентності вчителя, наведено огляд зарубіжного i вітчизняного досвіду навчання вчителів у сфері інформаційних технологій. Зазначено, що серед основних завдань діяльності ресурсних центрів дистанційної освіти є забезпечення відповідного кваліфікаційного рівня викладачів-тьюторів, які працюють у мережі ресурсних центрів. Виокремлено рівні ІКТ-компетентності, необхідних для успішної професійної діяльності мережних викладачів.
\end{abstract}

Ключові слова: дистанційна освіта; ресурсний центр дистанційної освіти; ІКТкомпетентність; рівні ІКТ-компетентності.

\section{1. ВСТУП}

\section{Постановка проблеми}

Сучасна освіта суттєво переймається питаннями компетенції і компетентностей в освітній галузі, оскільки саме компетентнісний підхід забезпечує розуміння життєвості отриманих у процесі навчання знань, умінь та навичок. Новими нормативно-правовими державними документами (Державним стандартом базової та повної загальної середньої освіти, Законом України “Про вищу освіту") визначено пріоритетними особистісно зорієнтований, компетентнісний і діяльнісний підходи, що відображені в результативних складових змісту освіти. Розвиток компетентісного підходу сприяв тому, що освітяни виокремили важливі ключові і найбільш інтегровані компетентності, які сприяють досягненню успіхів у житті; сприяють підвищенню якості суспільних інститутів; відповідають різним сферам життя. Так, у загальному розумінні компетентнісний підхід виявляється у спрямованості навчально-виховного процесу на досягнення результатів, якими $\epsilon$ ієрархічно підпорядковані ключова, загальнопредметна і предметна (галузева) компетентності.

У державному документі (Закон України "Про вищу освіту" стаття 1, п. 13) компетентність визначено як динамічну комбінацію знань, умінь і практичних навичок, способів мислення, професійних, світоглядних і громадянських якостей, моральноетичних цінностей, яка визначає здатність особи успішно здійснювати професійну і подальшу навчальну діяльність і $є$ результатом навчання на певному рівні вищої освіти.

Для порівняння 3 національними нормативними документами щодо визначення ключових термінів, які $\epsilon$ важливими для спільного розуміння сучасної освітньої політики у галузі професійної підготовки, у роботі Овчарук О. [11] наведено дані зарубіжних дослідників, зокрема Свропейського центру розвитку та професійного навчання (CEDEFOP), з питань визначення дефініції “компетентність”. Зазначений центр оприлюднив європейський багатомовний термінологічний глосарій, у якому поняття "навички" визначено, як “знання та досвід, що необхідні для виконання специфічних завдань та роботи”, а “компетентність” визначена як “доведена здатність 
застосовувати знання, навички, особистісні, соціальні та/або методологічні здатності у роботі та навчанні, а також у професійному та особистісному розвиткові”. Також у основних документах Свропейської Комісії зазначається компетентність як здатність застосовувати навчальні досягнення адекватно визначеним у контекстах (освіті, роботі, особистісному i професійному розвитку). Компетентність не обмежена лише когнітивними елементами; вона включає функціональні аспекти (включаючи технічні навички), особистісні якості (в т. ч. соціальні й організаційні навички) та етичні цінності.

Питання професійної компетентності кадрового складу фахівців дистанційного навчального процесу завжди були в центрі уваги освітньої установи будь-якого рівня акредитації, які тільки планують надавати дистанційні освітні послуги або вже використовують технології дистанційного навчання.

Як зазначають дослідники В. Кухаренко, Е. Полат та ін., дистанційне навчання це різновид відкритого навчання з використанням комп’ютерних і телекомунікаційних засобів, що забезпечують інтерактивну взаємодію викладачів/учителів і студентів/учнів на різних етапах навчання і самостійну роботу останніх із матеріалами інформаційної мережі, більшість з яких підготовлена викладачами [3]. У сучасному ДН спектр функцій, які виконує викладач, якого називають тьютором, змінюється: деякі відомі функції, які притаманні i традиційним формам навчання, стають домінуючими (наприклад, координація навчально-пізнавального процесу, коригувального курсу, який викладається, керівництво навчальними проектами, перевірка поточних завдань тощо), а деякі - виникають як нові (наприклад, консультування прід час складання індивідуального навчального плану, управління навчальними групами взаємопідтримки, допомоги учням або студентам у їх професійному самовизначенні, фільтрації мережних електронних джерел навчальної інформації, підготовки віртуальних навчальних ситуаційних завдань тощо). Перед педагогічним персоналом i організаторами дистанційної освіти ставиться завдання навчити суб'єкта навчання вчитися, сформувати у нього методологічний фундамент і сучасні технологічні прийоми навчання впродовж усього життя [1].

Розглянемо детальніше функціональні обов'язки педагогічних працівників РЦДО, задіяних у процесі дистанційного навчання, які передбачають:

- розроблення документів планування навчального процесу;

- розроблення і своєчасне оновлення змістовного, дидактичного та методичного наповнення веб-ресурсів навчальної програми;

- реалізацію навчальних заходів, передбачених навчальною програмою, включаючи консультації, семінари, дискусії, рольові ігри, лекції тощо як у синхронному, так і асинхронному режимах з використанням графічного, аудіо- $\mathrm{i}$ відеоформатів;

- індивідуалізацію навчального процесу шляхом персональної адаптації педагогічного сценарію і підвищення мотивації;

- проведення контрольних заходів;

- консультування під час навчання і підготовки випускних робіт;

- надання аналітичних звітів керівнику навчального закладу щодо результатів виконання навчальних програм [6].

Кваліфікаційні характеристики застосовуються як нормативні документи і можуть служити основою для розробки посадових інструкцій, що містять конкретний перелік посадових обов'язків працівників з урахуванням особливостей організації праці й управління, їх прав, відповідальності і професійної компетентності, зокрема у сфері ІКТ технологій. Наразі під професійною компетентністю розуміється якість дій працівника, що забезпечують адекватне й ефективне розв'язання професійно важливих 
предметних завдань дистанційного навчання, що мають проблемний характер, а також готовність нести відповідальність за свої дії.

Досвід практичної діяльності викладачів-тьюторів ресурсних центрів дистанційної освіти свідчить про існування низки проблем, які перешкоджають формуванню даного виду компетентності, а саме:

- не готовність викладачів до організації навчального процесу, орієнтованого на формування ІКТ компетентності, що полягає у незнанні іï суті і структури, критеріїв визначення рівня сформованості;

- перевантаженість навчального процесу, що створює дефіцит часу, необхідного для організації відповідної професійної діяльності.

Отже, аналіз наукових праць, присвячених дослідженню компетентності засвідчив, що це поняття є інтегрованим і багатокомпонентним, проте його складові, a також етапи їх розвитку вченими визначаються відповідно до різного методологічного підгрунтя. Проте, вивчення наукових джерел дозволяє стверджувати, що питання, пов'язані 3 підготовкою висококваліфікованого, зокрема 3 високим рівнем інформаційно-комунікаційно-технологічної (IКТ) компетентності кадрового складу фахівців для ефективного функціонування ресурсних центрів дистанційної освіти на базі навчального закладу вивчено ще недостатньо.

Аналіз останніх досліджень і публікацій. Розвиток дистанційної освіти в Україні пов'язаний з іменами таких учених як Биков В., Богачков Ю., Гриценко В., Жалдак М., Згуровський М., Кухаренко В., Лапінський В., Манако А., Морзе Н., Олійник В., Пінчук О., Стефаненко П., Щенніков С та ін. Проблеми реалізації компетентнісного підходу в процесі професійної підготовки вчителя, конкретизації змісту його професійних компетентностей досліджували Савченко О., Пометун О., Котенко В., Пєтухова Л., Раков С., Спірін О, Овчарук О., Локшина О. та ін.

Проблеми впровадження дистанційного навчання досліджено у роботах закордонних учених, серед яких Бергер Р., Беккер Х., Бленк Б., Бриттел Д., Деллінг Р., Рамблє Г., Каган Д., Сімонсон М., Мур М., Кларк А., Томпсон М., Хассон Дж та інші. Проблеми розвитку компетентнісного підходу, які виокремили ключові, найбільш інтегровані компетентності, висвітлено у роботах Дж. Равен, Л. Салганік, Д. Рікен, У. Мозер, М. Спектор та ін. [13].

Серед російських учених питання дистанційної освіти досліджували Андрєєва А., Бухаркіна М., Моїсеєва М., Петров А., Полат Є., Хуторський А., Тихомирова О. Шихмурзаєва А. та ін.

Метою даної статті є обгрунтування методологічних підходів щодо формування інформаційно-комунікаційно-технологічної (ІКТ) компетентності викладачів-тьюторів і визначення іiі рівнів для ефективного функціонування ресурсних центрів дистанційної освіти навчальних закладів.

\section{2. МЕТОДИ ДОСЛІДЖЕННЯ}

Під час проведеного дослідження щодо вивчення питань ІКТ-компетентності педагогічних і науково-педагогічних працівників і визначення іiї рівнів, що сприятиме ефективному функціонуванню ресурсних центрів дистанційної освіти, було використано комплекс теоретичних i емпіричних методів, серед яких: системний i порівняльний аналіз психолого-педагогічної, навчально-методичної та науковотехнічної літератури з проблем дослідження; узагальнення тощо. 


\section{3. РЕЗУЛЬТАТИ ДОСЛІДЖЕННЯ}

За результатами досліджень вітчизняних учених, у системі дистанційного навчання від викладача вимагається низка спеціальних умінь, зокрема:

- мати широкий кругозір щодо питань застосування інформаційнокомунікаційних технологій в освіті;

- володіти комп'ютерною грамотністю на рівні кваліфікованого користувача;

- уміти працювати з локальною і корпоративною мережами (Інтранет/Інтернет) у межах доступу до своєї категорії користувача;

- мати чітке уявлення про технології, методики та форми організації дистанційного навчання;

- уміти проектувати і створювати електронні цифрові ресурси;

- володіти навичками інтерактивних форм взаємодії зі студентами;

- знати і застосовувати форми контролю знань, умінь та навичок в умовах Інтернет-освіти;

- вести електронну документацію;

- знати і враховувати в роботі педагогічні і психологічні основи дистанційного навчання [4].

Для більш детального дослідження проблемного питання розглянемо функції й нову роль викладача-тьютора в системі дистанційного навчання.

Тьютор або викладач-консультант організовує ефективне вивчення курсу, проводить семінари і консультує студентів, перевіряє і коментує письмові завдання. Специфіка дистанційного навчання (стислість занять, їх інтенсивний характер, робота 3 дорослими) висуває до викладача-тьютора вимоги, які істотно відрізняються від традиційних, як за особистісними якостями, так і методиками навчання.

Викладач-тьютор створює освітнє середовище, що дозволяє учневі/студентові здобути знання і навички, розв'язувати реальні проблеми у своїй діяльності. Наразі тьютор допомагає максимально ефективно використовувати різноманітні навчальні матеріали, Інтернет, практичний досвід інших студентів. Безсумнівно, викладач у системі дистанційного навчання повинен володіти Інтернет-технологіями, технологією електронної пошти, комп'ютерними навчальними програмами, чат-технологією, Webтехнологіями тощо. Безперервний розвиток тьюторів забезпечується за рахунок формування професійного тьюторського середовища. Тьютор має можливість взаємодіяти з колегами, беручи участь у постійно діючих Інтернет-конференціях, виїзних школах тьюторів, різних семінарах, авторських семінарах, конференціях. Використовуючи ці різноманітні форми взаємодії, обмінюються досвідом, дізнаються про нові компоненти курсів, створюють спільне бачення підходів до проведення занять й оцінювання. Тьюторіал у дистанційному навчанні — це очне заняття, проведене тьютором на основі активних методів навчання i спрямоване як на засвоєння студентами певного матеріалу, так і на контроль знань, умінь і навичок студентів. Тому викладач має володіти сучасними педагогічними і комп'ютерними технологіями.

Тьютори поєднують у собі якості:

- викладача - проводять тьюторські заняття; допомагають студентам у навчанні; забезпечують правильну організацію і контроль самостійної роботи, ефективне використання навчально-методичної літератури тощо;

- консультанта - координують пізнавальний процес студентів; проводять групові й індивідуальні консультації, комунікативні заняття тощо;

- менеджера - організовують процес навчання за індивідуальним графіком, управляють проведенням групових тьюторських занять; контролюють 
виконання студентами контрольних заходів (вхідний, поточний та підсумковий контроль).

Тьютори мають пройти попередню психолого-педагогічну підготовку. Виконувати функції тьютора можуть досвідчені викладачі з високими професійними, організаторськими, комунікативними, управлінськими та іншими якостями.

До професійних обов'язків тьютора входить:

- створення сприятливих умов для організації і контролю самостійної роботи студентів;

- проведення індивідуальних і групових консультацій студентів;

- надання науково-методичної допомоги студентам у процесі навчання;

- забезпечення правильного й ефективного використання навчально-методичної літератури;

- координування самостійної навчальної діяльності студентів під час позааудиторної самостійної роботи;

- перевірка самостійних письмових домашніх завдань [2].

Тьютор виконує функції керівника, координатора, консультанта. До нього звертаються як до авторитетного джерела інформації, як до експерта. Змінюються форми співробітництва викладачів і студентів. Обговорення поточних результатів у групі, дискусії, «мізкові атаки», доповіді, виступи набувають дещо іншого характеру. Тому до тьютора висуваються високі професійні і ділові вимоги: він має володіти не лише вміннями наукової, педагогічної, методичної діяльності, йому повинні бути притаманні комунікативні, організаторські, менеджерські вміння і якості.

Вважаємо доцільним визначити основні характеристики діяльності викладачатьютора, а саме:

- допомагає прояву активності у віртуальному середовищі і повсякчасно мотивує навчальну діяльність;

- працює індивідуально, дає поради або консультації щодо допомоги отримати задоволення від вивчення курсу;

- визначає через зворотний зв'язок доцільність і правильність навчальної діяльності студента/учня;

- визначає необхідність залучення до процесу нових знань, що відповідають змісту навчання і здатні підвищити його якість;

- визначає напрямок зростання студента/учня у розумінні змісту курсу;

- визначає стратегію і якість виконання або необхідну допомогу у виконанні технологічного вибору, що покращують умови навчального простору студента/учня;

- визначає задачі проектування як у курсі, так і у просторі курсу, на які доречно звернути увагу, i конструює додаткові засоби діяльності, які мають удосконалити проведення курсу;

- визначає проблеми реєстрації студента/учня, збереження записів та ін.

Отже, узагальнюючи вищевикладений матеріал нашого дослідження, більш детально розглянемо компетентності у сфері інформаційно-комунікаційних технологій, які характеризують відповідні вміння і навички педагогічних і науково-педагогічних працівників, зокрема тих, що забезпечують процес дистанційного навчання.

Питанням, пов'язаним 3 виокремленням і трактуванням поняття інформаційнокомунікаційної компетентності (IK), присвячені дослідження Вембер В., Кузьминської О., Морзе Н., Овчарук О., Спіріна О. та ін.

У роботі [6] визначено, що ІК-компетентність $є$ результатом різнобічних здатностей людини й має такі складові:

здатності та вміння: 
- здобувати інформацію з різних джерел у зрозумілому вигляді;

- працювати з різними відомостями;

- критично оцінювати відомості;

- використовувати у професійній діяльності інформаційно-комунікаційні технології;

знання:

- основ ергономіки й інформаційної безпеки;

- функціональних можливостей IКТ;

- конкретні навички з використання комп'ютерної техніки та IКТ;

- ставлення особистості до застосування ІКТ для відповідальної соціальної взаємодії та поведінки. (О. В. Овчарук, О. М. Спірін) [6].

Здійснений дослідниками аналіз у роботі[11] доводить, що у міжнародних колах дане поняття не звужено до технологічної або цифрової галузі, воно містить різні аспекти, до яких відносяться соціальна сфера, галузь комунікацій, ціннісні й громадянські аспекти життєдіяльності людини. Характерним є те, що кожен автор трактування поняття "ІК-компетентність" максимально наближає до близької йому сфери. Саме тому у різних наукових роботах зустрічаємо авторські трактування даного поняття, де кожен автор, іноді штучно “притягує” сферу свого дослідження до власного визначення поняття ІК-компетентності.

Спираючись на визначення багатьох вищезазначених дослідників, у Науковометодичних рекомендаціях до проекту державних стандартів інформативних компетентностей учителів [14] інформаційна компетентність визначена як підтверджена здатність особистості використовувати інформаційні технології для гарантованого донесення й опанування інформації 3 метою задоволення власних індивідуальних потреб і суспільних вимог щодо формування загальних і професійноспеціалізованих компетентностей людини.

Дослідники Беспалько В розглядають ІК-компетентність як інтегральну характеристику особистості; Слізаров О. як сукупність знань, умінь і досвіду діяльності з IКТ; Шилова О,. Лебєдєва М. як здатність індивіда розв' язувати професійні завдання засобами IКТ; Насирова Н. як мотивацію, потребу й інтерес до отримання знань, умінь i навичок з ІКТ; Овчарук О. як здатність орієнтуватися в інформаційному просторі тощо.

Інформаційна компетентність - якість дій працівника, що забезпечують ефективний пошук, структурування інформації, ऑï адаптацію до особливостей педагогічного процесу i дидактичних вимог, формулювання навчальної проблеми різними інформаційно-комунікативними способами, кваліфіковану роботу з різними інформаційними ресурсами, професійними інструментами, готовими програмнометодичними комплексами, що дозволяють проектувати розв'язання педагогічних проблем i практичних завдань, використання автоматизованих робочих місць педагогічного i науково-педагогічного працівника в освітньому процесі; регулярну самостійну пізнавальну діяльність, готовність до ведення дистанційної освітньої діяльності, використання комп'ютерних i мультимедійних технологій, цифрових освітніх ресурсів у освітньому процесі, ведення документації навчального закладу на електронних носіях.

Дослідники у своїй роботі [11], узагальнюючи питання щодо ІК-компетентності, зазначають, що під цим поняттям необхідно розуміти доведену здатність працювати індивідуально або колективно, використовуючи інструменти, ресурси, процеси та системи, які відповідають за доступ й оцінювання інформації, отриманої через будь-які медія ресурси, і використовувати таку інформацію для розв'язання проблем, спілкування, створення інформованих рішень, продуктів та систем, а також для отримання нових знань. 
Отже, дослідники Гуржій А., Овчарук О. [11], зазначають, що розбіжності у визначенні понять, які стосуються формування і застосування сфери IКT, тісно пов'язані з контекстом, у якому вони застосовуються. Так, наприклад, у звітах Організації економічного співробітництва та розвитку підтримується думка, що нечітка термінологія в даному питанні існує через застосування різної термінології щодо сфери ІКТ відповідно до стану розвитку суспільства та інших сфер - нова економіка, еекономіка, ІКТ-сектор та ін. Це означає, що ці поняття змінюються залежно від рамок застосування. У зарубіжних системах освіти в межах поняття IК-компетентності лежать також такі: цифрова грамотність, технологічна грамотність, інформаційна i технологічна грамотність, технологічна грамотність, ІКТ-компетентність інформаційно-комунікаційно-технологічна компетентність, ІКТ-навички інформаційно-комунікційно-технологічні навчики та ін.

У дослідженнях Спіріна О. інформаційно-комунікаційні технології визначено як - технології розробки інформатичних систем і побудови комунікаційних мереж, а також технології формалізації і розв’язування задач у певних предметних галузях 3 використанням таких систем і мереж. Інформаційно-комунікаційна компетентність, точніше інформаційно-комунікаційно-технологічна компетентність(IKT) компетентність - це підтверджена здатність особистості використовувати на практиці інформаційно-комунікаційні технології для задоволення власних індивідуальних потреб і розв'язування суспільно-значущих, зокрема професійних, задач у певній предметній галузі [14].

Узагальнення різних науково-теоретичних підходів дає підстави стверджувати, що ІКТ-компетентність вчителя-тьютора в роботі РЦДО визначено як системну якість особистості, що характеризується єдністю професійних знань, умінь та навичок у галузі інформаційних технологій, ціннісних настанов та особистісного ставлення до них. Має багаторівневу i багатокомпонентну структуру i розвивається протягом усього професійного буття викладача.

Грунтуючись на теоретико-методологічних засадах компетентнісного підходу, у структурі ІКТ-компетентності доцільно виділити такі іï компоненти:

- мотиваційно-цільовий - охоплює інтереси, потреби, мотиви, мету професійного навчання, вдосконалення, саморозвитку у сфері ІКТ; ціннісні настанови і творчі прояви щодо використання ІКТ у професійній діяльності;

- когнітивний - визначається повнотою, глибиною, системністю знань викладача-тьютора про сучасні інформаційно-комунікаційні технології, їх роль у предметній сфері, знаннями способів діяльності із застосуванням IКТ для роботи з інформаційними об' єктами тощо;

- операційно-діяльнісний - виявляє активне застосування педагогом інформаційних технологій і комп'ютера в професійній діяльності як засобів формування і розвитку ІКТ-компетентності, самовдосконалення й творчості, а також виховання подібних якостей у суб' єктів навчального процесу;

- рефлексивний - визначає ставлення викладача до себе і до світу, до власної практичної діяльності та іiі здійснення 3 використанням IKT; наявність самосвідомості, самоконтролю, самооцінки, розуміння та відповідальності за результати своєї діяльності, пізнання себе і самореалізації в професійній діяльності через засоби IКТ.

У сучасних дослідженнях для опису індикаторів інформаційно-комунікаційних компетентностей використано підхід ISTE - Міжнародної спільноти 3 технологій в освіті й виділено шість рівнів, а саме:

1) початковий,

2) мінімальний базовий, 
3) базовий,

4) поглиблений,

5) дослідницький,

6) рівень експерта [11].

Варто зазначити, що в науковій літературі рівні сформованості ІКТкомпетентності мають неоднозначне трактування. Проте, спираючись на вищезазначений розподіл, розкриємо більш детально зміст кожного рівня стосовно ІКТ-компетентності викладача-тьютора РЦДО.

I рівень, початковий. Початковий рівень - такий рівень ІКТ-компетентності викладача-тьютора РЦДО, який розуміє важливість і необхідність інформаційнокомунікаційних технологій для розвитку освіти. Цей рівень вимагає від викладача підтвердженої здатності демонструвати розуміння ролі і значення IКТ для здійснення педагогічної діяльності, демонструвати елементарне розуміння суті й історії розвитку інформаційно-комунікаційних технологій, що використовуються у певній предметній галузі, демонструвати своє відношення до інноваційного розвитку навчального закладу й упровадження IKT у навчально-виховний процес; демонструвати спроби моделювання навчального процесу з використанням IКТ.

II рівень, мінімальний базовий. Мінімальний базовий рівень - такий рівень IКТкомпетентності викладача-тьютора, який уміє користуватися готовими програмними продуктами у власній діяльності. Вимагає від викладача підтвердженої здатності описувати принципи і поняття, що лежать в основі конкретної ІКТ, активізувати пізнавальну діяльність засобами ІКТ, уміти відібрати комп'ютерні програми і ППЗ 3 метою використання під час викладання конкретного предмета, демонструвати знання IКТ для унаочнення навчального матеріалу, уміння описувати власні потреби з ІКТ для організації власного робочого місця.

III рівень, базовий. Базовий рівень - такий рівень ІКТ-компетентності викладача-тьютора, який знає й уміє використовувати основні поняття ІКТ. Вимагає від учителя підтвердженої здатності створювати відповідні умови для розвитку здібностей учня, індивідуалізації діяльності учнів, використовуючи для цих цілей усі можливі сучасні ІКТ і різноманітні стилі навчання; постійно наповнювати і працювати над створенням технологічно-насиченого навчального середовища, узагальнювати передовий педагогічний досвід із використання конкретних IКТ для навчання учнів, упевнено користуватися базовими ІКТ для налагодження співпраці з батьківським комітетом, здійснювати оцінювання власної діяльності, упевнено добирати й використовувати ІКТ для розв'язування основних професійних задач. Узагальнюють передовий педагогічний досвід. Демонструють лідерство, ефективно просуваючи IКТ у предметній галузі

$\boldsymbol{I V}$ рівень, поглиблений. Поглиблений - такий рівень інформаційнокомунікаційної компетентності вчителя, який вільно оперує знаннями 3 IКТ у професійній діяльності. Вимагає від викладача підтвердженої здатності розв'язувати професійні задачі підвищеної складності, нестандартних, інноваційних як теоретичного, так і практичного характеру з використанням IКТ, використовувати методи критичного аналізу й розвитку теорій інформаційно-комунікаційних технологій, планувати кроки до опанування об' ємною базою знань з ІКТ, бути здатним проектувати, конструювати і вносити інновації до елементів наявних IKT, які використовуються під час навчання; демонструвати: інноваційний професіоналізм, необхідний для цифрового суспільства, вільно володіти засобами Інтернет-ресурсів; вести активну співпрацю з колегами.

$\boldsymbol{V}$ рівень, дослідницький. Дослідницький - такий рівень ІКТ компетентності викладача, який дозволяє фахівцю вільно оперувати знаннями 3 IKT, Інтернет- 
ресурсами і використовувати їх у дослідницькій, проектній діяльності. Вимагає від викладача підтвердженої здатності вільного володіння предметною галуззю. Включає здатність демонструвати і застосовувати новітні теорії і їх інтерпретації, критично відстежувати, осмислювати розвиток теорії і практики, зокрема критично оцінювати нові ідеї і доведення з різних джерел; використовувати низку спеціалізованих навичок й оцінювати різноманітні повідомлення для того, щоб спланувати стратегію дослідження; пропагувати легітимне і безпечне використання цифрової інформації; висловлювати необхідність дотримання авторського права, прав інтелектуальної власності, демонструвати знання цифрової культури; активно співпрацювати 3 усіма учасниками навчально-виховного процесу і залучати колег до участі у соціальних мережах, які вивчають, удосконалюють, упроваджують освітні IКТ, активно працювати 3 учнями в Інтернет-проектах, використовують у своїй роботі соціальні сервіси, Інтернет-портали; брати участь у конкурсах педагогічної майстерності з використанням IKT, забезпечувати педагогічну діяльність новітніми методами дослідження i пояснювати його результати, використовуючи IКT; демонструвати власний педагогічний досвід із питань використання ІКТ.

VI piвень, ексnерma. Рівень експерта - такий рівень інформаційнокомунікаційної компетентності вчителя, який дозволяє вчителеві вільно оперувати знаннями з IКТ, Інтернет-ресурсами, оцінювати інноваційний розвиток IКТ і виступати як експерт з питань впровадження ІКТ у навчально-виховний процес. Демонструють лідерство в питаннях інтеграції технологій. Вимагає від викладача підтвердженої здатності демонструвати повне володіння предметною галуззю інформаційнокомунікаційних технологій, володіти новітніми методами незалежного дослідження і пояснювати його результати на просунутому рівні, робити оригінальний вклад у розвиток IКТ, демонструючи володіння методологією і вмінням вести критичний діалог $з$ колегами, здатен розв'язувати інноваційні професійні задачі теоретичного й практичного характеру в галузі ІКТ, зокрема з моделювання, проектування, розробки, упровадження, налагодження нових інформаційно-комунікаційних технологій i управління ними, демонструвати лідерство в питаннях інтеграції технологій, демонструвати систему впровадження ІКТ під час викладання конкретного предмета $\mathrm{i}$ організації навчально-виховної роботи на рівні експерта, сприяти ефективності, життєздатності й оновленню професії вчителя; забезпечувати ефективну практику 3 вивчення технологій і їх інтегрування для роботи з обдарованими учнями, учнями 3 особливими потребами, демонструвати застосування новітніх технологій для індивідуалізації навчання, підтримують власний професійний розвиток і демонструють бажання до підвищення власного рівня ІКТ-компетентності, дотримуються принципу освіти впродовж життя.

\section{4. ВИСНОВКИ ТА ПЕРСПЕКТИВИ ПОДАЛЬШИХ ДОСЛІДЖЕНЬ}

Отже, на підставі вищезазначеного можна дійти певних висновків:

Рівень ІКТ-компетентності фахівців, задіяних у роботі ресурсних центрів дистанційного навчання, має відповідати міжнародним стандартам і національним нормативним документам, наявним на сьогоднішній день.

Узагальнення різних науково-теоретичних підходів дає підстави стверджувати, що ІКТ-компетентність учителя-тьютора в роботі РЦДО визначено як системну якість особистості, що характеризується єдністю професійних знань, умінь та навичок у галузі інформаційних технологій, ціннісних настанов і особистісного ставлення до них. Має багаторівневу i багатокомпонентну структуру i розвивається протягом усього професійного буття викладача, передбачає здатність орієнтуватися в інформаційному 
просторі, оперувати даними на основі використання сучасних ІКТ відповідно до потреб ринку праці та для ефективного виконання професійних обов’язків. Слід додати, що ця компетентність має також включати такі елементи, як ціннісні орієнтації, тобто критичний погляд i критичний аналіз відомостей i даних, що складають зміст, отриманий з різних джерел і за допомогою ІКТ.

Під час дослідження було виявлено рівні ІКТ-компетентності фахівців, задіяних у роботі ресурсних центрів дистанційного навчання.

1. І рівень початковий - передбачає формування оптимального інваріанта знань і вмінь, пов'язаних з використанням ІКТ у навчальному процесі на рівні користувача.

2. ІІ рівень мінімальний базовий - розробляють модель пізнавальної діяльності учнів із використанням ІКТ. Оцінюють існуючі комп'ютерні програми і ППЗ з метою використання у конкретній предметній галузі. Виявляють потребу в підвищенні власного рівня IКТ.

3. III рівень базовий - відповідає усвідомленому методично грамотному використанню IКТ у викладанні свого предмета зі здатністю надавати допомогу й консультації своїм колегам й учням; створюють технологічно насичене навчальне середовище. Впроваджують принципи ефективного використання IКT.

4. IV рівень, поглиблений - демонструють інноваційний професіоналізм, необхідний для цифрового суспільства. Розв'язують нестандартні, інноваційні професійні задачі теоретичного й практичного характеру 3 використанням IКТ. Демонструють рівень ІКТ і власний стиль для оцінювання, аналізу і узагальнення навчальних досягнень учнів, упроваджуючи різні навчальні і тестові програми.

5. V piвень, дослідницький - розглядається як здатність і готовність педагога передавати свої знання у сфері ІКТ колегам і пов'язана з підготовкою викладачатьютора, наставника навчання. Демонструють знання цифрової культури. Залучають колег до участі у соціальних мережах, які вивчають, удосконалюють, впроваджують освітні ІКТ. Працюють з учнями в Інтернет-проектах, використовують у своїй роботі соціальні сервіси, Інтернет-портали. Беруть участь у конкурсах педагогічної майстерності з використанням ІКТ. Забезпечують педагогічну діяльність новітніми методами дослідження і пояснюють його результати, використовуючи IКТ.

6. VI piвень, експерта. Рівень експерта - такий рівень інформаційнокомунікаційної компетентності вчителя, який дозволяє вчителеві вільно оперувати знаннями з IКТ, Інтернет-ресурсами, оцінювати інноваційний розвиток IКТ і виступати як експерт з питань впровадження ІКТ у навчально-виховний процес. Демонструють лідерство в питаннях інтеграції технологій.

Отже, результати здійсненого аналізу державної системи перепідготовки і підвищення кваліфікації педагогічних кадрів у сфері ІКТ свідчать, що проблема сформованості ІКТ компетентності фахівців, залучених до процесу дистанційного навчання у ресурсних центрах розв'язується в кожному навчальному закладі порізному. В Україні досі не впроваджено єдиного технологічного стандарту для вчителів, відсутній механізм оцінювання рівня їх ІКТ-компетентності, не здійснюється сертифікація педагогів за міжнародними стандартами, відсутня єдина стратегія підвищення кваліфікації вчителів у сфері ІКТ, відсутні мотиваційні заходи щодо підтримки ініціатив педагогів з упровадження ІКТ у навчально-виховний процес.

Перспективи подальших досліджень спрямовані на вивчення питань щодо моніторингу рівнів ІКТ-компетентностей фахівців, залучених до процесу дистанційної освіти.

\section{СПИСОК ВИКОРИСТАНИХ ДЖЕРЕЛ}


1. Биков В. Ю. Сучасні завдання інформатизації освіти / В. Ю. Биков. // Інформаційні технології i засоби навчання : електронне наукове фахове видання [Електронний ресурс] / Ін-т інформ. технологій і засобів навчання АПН України, Ун-т менеджменту освіти АПН України; гол. ред.: В. Ю. Биков. — 2010. — № 1(15). — Режим доступу : http://www.ime.edu-ua.net/em15/emg.html.

2. Дерба Т. О. Функціональні обов'язки тьютора мереженого дистанційного навчання школярів / Т. О. Дерба // Інформаційні технології і засоби навчання : електронне наукове фахове видання [Електронний ресурс]. — 2010. — № 5(19). — Режим доступу до журналу : http://www.ime.eduua.net/em.html.

3. Биков В. Ю., Кухаренко В. М., Сиротенко Н. Г., Рибалко О. В., Богачков Ю. М. Технологія розробки дистанційного курсу : навчальний посібик. - К. : Міленіум, 2008. - 323 с.

4. Жевакіна Н. В. Професійні функції діяльності викладача-тьютора в умовах дистанційного навчання / Н. В. Жевакіна, М. А. Семенов // Вісник ЛНУ імені Тараса Шевченка. — 2011. — №5 (216). - C. 5-9.

5. «Про затвердження кваліфікаційних характеристик професій (посад) педагогічних та науковопедагогічних працівників навчальних закладів». Наказ МОН № 665 від 01.06.13 року [Електронний ресурс]. — Режим доступу : http://osvita.ua/legislation/other/37302/list/2/.

6. Основи стандартизації інформаційно-комунікаційних компетентностей в системі освіти України : метод. рекомендації /[В. Ю. Биков, О. В. Білоус, Ю. М. Богачков та ін.] ; за заг. ред. В. Ю. Бикова, О. М. Спіріна, О. В. Овчарук. - К. : Атіка, 2010. - 88 с.

7. Організація середовища дистанційного навчання в середніх загальноосвітніх навчальних закладах : посібник / [Богачков Ю. М., Биков В. Ю, Пінчук О. П., Манако А. Ф. та ін.] ; під наук. ред. Ю. М. Богачкова. - К. : Педагогічна думка, 2012. - 160 с.: іл.

8. Богачков Ю. М. Ключові питання створення Концепції мережі ресурсних центрів дистанційної освіти загальноосвітніх навчальних закладів / Ю. М. Богачков, О. П. Пінчук // Інформаційні технології і засоби навчання. - 2013. - № 3 (35). — С. 83-98. — Режим доступу : http://journal.iitta.gov.ua/index.php/itlt/article/view/854.

9. Типове положення про ресурсний центр дистанційної освіти системи загальної середньої освіти. [Електронний ресурс]. - Режим доступу : http://lib.iitta.gov.ua/id/eprint/406.

10. «Про затвердження Вимог до вищих навчальних закладів та закладів післядипломної освіти, наукових, освітньо-наукових установ, що налають освітні послуги за дистанційною формою навчання 3 підготовки та підвищення кваліфікації фахівців за акредитованими напрямами i спеціальностями». Наказ МОН України № 1518 від 30.10.2013 р [Електронний ресурс]. — Режим доступу : http://ipo.kpi.ua/fileadmin/template/Nakaz_Vimogi_30_10_13.pdf.

11. Овчарук, О. В., Гуржій, А. М. Дискусійні питання інформаційно-комунікаційної компетентності: міжнародні підходи та українські перспективи Інформаційні технології в освіті : Збірник наукових праць. Випуск 15. - Херсон: ХДУ, 2013. - С. 38-42.

12. Коневщинська О. Е. Кадрове забезпечення ресурсного центру дистанційного навчання / О .Е. Коневщинська // Інформаційні технології і засоби навчання. — 2013. — № 6 (38). — C 182195. - Режим доступу : http://journal.iitta.gov.ua/index.php/itlt/article/view/957\#.U6bQSZR_vVI.

13. Laura H. Salganik, Dominique S. Rychen, Urs Moser, John W. Konstant (1999), Projects on Competencies in the OECD Context: Analysis of Theoretical and Conceptual Foundations, SFSO, OECD, ESSI, Neuchatel.

14. Науково-методичні рекомендації до проекту державних стандартів інформативних компетентностей вчителів [Електронний ресурс]. — Режим доступу : http://lib.iitta.gov.ua/1918/1 _.pdf.

Матеріал надійшов до редакиї 26.09.2014 p.

\title{
ФОРМИРОВАНИЕ ИКТ-КОМПЕТЕНТНОСТИ ПРЕПОДАВАТЕЛЕЙ- ТЬЮТОРОВ РЕСУРСНЫХ ЦЕНТРОВ ДИСТАНЦИОННОГО ОБРАЗОВАНИЯ
}

\author{
Коневщинская Ольга Эммануиловна \\ кандидат педагогических наук, ученый секретарь \\ Институт информационных технологий и средств обучения НАПН Украины, г. Киев, Украина \\ olgak1972@mail.ru
}

Аннотация. В статье проанализированы основные подходы формирования ИКТкомпетентности категории специалистов, которые осуществляют учебно-методическую 
поддержку процесса дистанционного обучения. Освещена степень научной разработки проблемы, определена и обоснована сущность ИКТ-компетентности учителя, приведен обзор зарубежного и отечественного опыта обучения учителей в сфере информационных технологий. Указано, что среди основных задач деятельности ресурсных центров дистанционного образования является обеспечение соответствующего квалификационного уровня преподавателей-тьюторов, которые работают в сети ресурсных центров. Выделены уровни ИКТ-компетентности, необходимые для успешной профессиональной деятельности сетевых преподавателей.

Ключевые слова: дистанционное образование; ресурсный центр дистанционного образования; ИКТ-компетентность; уровни ИКТ-компетентности.

\title{
FORMATION OF TEACHERS-TUTOR ICT COMPETENCE OF DISTANCE EDUCATION RESOURCE CENTERS
}

\author{
Olga E. Konevchshynska \\ Ph.D. (in Pedagogics), scientific secretary \\ Institute of Information Technologies and Learning Tools of NAPS of Ukraine, Kyiv, Ukraine \\ olgak1972@mail.ru
}

\begin{abstract}
The paper analyzes the main approaches to the definition of ICT competence of professionals who provide training and methodological support of distance learning. There is highlighted the level of scientific development of the problem, identified and proved the essence of teacher's ICT competence, overviewed the international and domestic experience of teacher training in the the sphere of information technologies. It is indicated that one of the main tasks of resource centers for distance education is the provision of an appropriate level of qualification of teacher-tutor working in a network of resource centers. Also it is pointed out the levels of ICT competencies necessary for successful professional activity of network teachers.
\end{abstract}

Keywords: distance education; center for distance education; ICT competence; levels of ICT competence.

\section{REFERENCES (TRANSLATED AND TRANSLITERATED)}

1. Bykov V. Y. Modern task information education [online] / V. Bykov / Information technology and learning tools: electronic scientific specialized edition / Inst inform. technology and training Sciences of Ukraine, University of Management Education Pedagogical Sciences of Ukraine, Ch. eds.: V. Bykov. 2010. — № 1 (15). — Available from:http://www.ime.edu-ua.net/em15/emg.html (in Ukrainian).

2. Derba T. O. Functional responsibilities tutor of network distance education students [online] / T. O. Derba // Information technology and learning tools: electronic scientific specialized edition. 2010. — № 5 (19). — Available from : http://www.ime.edu-ua.net/em.html (in Ukrainian).

3. Bykov V. Y, Kuharenko V. M, Sirotenko N. G Rybalko O. V Bohachkov Y. M. Technology development of distance learning course. Manual. - K. : Millennium, 2008. - 323 p. (in Ukrainian).

4. Zhevakina N. V. Professional business features teacher-tutor in terms of distance education / N. V. Zhevakina, M. A. Semenov // Bulletin LNU Taras Shevchenko. — 2011. — №5 (216). — P. 5-9 (in Ukrainian).

5. On approval of job descriptions professions (positions) teaching and teaching staff of educational institutions. Order of the Science of Ukraine № 665 from 01.06.13 year [online]. — Available from : http://osvita.ua/legislation/other/37302/list/2/ (in Ukrainian).

6. Fundamentals of standardization of information and communication competencies in the education system of Ukraine: method. recommendations / [V. Bykov, O. Bilous, Y. Bohachkov et all.], For the Society. eds. V .Bykov, O. Spirin, O. Ovcharuk. — K. : Atika, 2010. — 88 p. (in Ukrainian).

7. Organization learning environment in secondary schools: a guide [Text] / [BohachkovYu. M., BykovV. Yu., Pinchuk O. P., Manako A. F. ta in.]. — K. : Pedahohichna dumka, 2012. — 160 s. (in Ukrainian).

8. Bohachkov Yu. M The key issue of establishing a network of resource centers concept of distance education secondary schools [online] / M. Bohachkov, O. Pinchuk // Information technology and learning tools. - 2013. — № 3 (35). - P. 83-98. — Available from : http://journal.iitta.gov.ua/index.php/itlt/article/view/854 (in Ukrainian). 
9. The default position of the Center for Distance Education of the general secondary education [online]. Available from : http://lib.iitta.gov.ua/id/eprint/406 (in Ukrainian).

10. Requirements for higher education and post-graduate education, research, educational and scientific institutions Setting educational services for distance learning with training and professional development for accredited and specialties." Order of the Science of Ukraine № 1518 of 10.30.2013 p [online]. Available from : http://ipo.kpi.ua/fileadmin/template/Nakaz_Vimogi_30_10_13.pdf(in Ukrainian)

11. Ovcharuk, O. V., Gurzhiy, A. M. Discussions about information and communication competence: international approaches and perspectives of Ukrainian IT in Education: Collected Works. Issue 15. Kherson: KSU, 2013. - S. 38-42. (in Ukrainian).

12. Konevschynska O. E. Staff of the Center for Distance Learning [online] / O. E. Konevschynska // Information technology and learning tools. - 2013. - № 6 (38). - P. 182-195. - Available from : http://journal.iitta.gov.ua/index.php/itlt/article/view/957\#.U6bQSZR_vVI (in Ukrainian).

13. Laura H. Salganik, Dominique S. Rychen, Urs Moser, John W. Konstant (1999), Projects on Competencies in the OECD Context: Analysis of Theoretical and Conceptual Foundations, SFSO, OECD, ESSI, Neuchatel (in English).

14. Scientific and guidelines to draft standards informative competencies of teachers [online]. - Available from : http://lib.iitta.gov.ua/1918/1_.pdf (in Ukrainian). 